\title{
Standardized patient in small group teaching: facilitating the small group
}

\author{
Ensino em grupos pequenos em grupos padronizados: \\ facilitando os pequenos grupos
}

\section{Enseñanza en grupos pequeños con pacientes estandarizados: facilitar grupos pequeños}

\author{
Heidi A. Lane," Beth H. Ipock
}

\begin{abstract}
Small group teaching is used frequently in medical education to provide an opportunity for performance based instruction in problem-solving, communication, and team work. Principles used to help medical students learn to assess and manage their patients may be integrated into small groups for formative education. This article describes an application of a successful model of human simulation based interaction (standardized patients) to a clinical development program in a problem-based learning environment. Evidence of institutions using this methodology will be included in the discussion assessing the scope and practical application. Description of both faculty facilitator and learner roles in small group experiential learning settings with standardized patients will be provided, as well as a brief discussion of assessment techniques using both formative and summative feedback. This method uses scenarios derived from real case examples that are structured to provide common challenges. It uses trained standardized patients to portray patients and to give live and immediate feedback to learners. Live learner simulations give participants a true experiential learning opportunity in a classroom without risk of harming real patients. A realistic practice scenario allows learners to practice and receive valuable feedback from other learners, faculty and standardized patients. This article will describe one application of this method in medical education to teach students patient-centered communication.
\end{abstract}

Keywords: Active learning; Curriculum, Problem-based; Experiential learning; Patient simulation; Education, Medical, Undergraduate.

\section{Resumo}

Ensino em pequenos grupos é usado com frequência na educação médica para oferecer uma oportunidade de instrução baseada no desempenho da resolução de problemas, comunicação e trabalho de equipe. Princípios usados para ajudar estudantes de medicina a aprender a avaliar e gerir os seus pacientes podem ser integrados em pequenos grupos para a educação formativa. Este artigo descreve uma aplicação de um modelo bem sucedido de interação baseado em simulação humana (pacientes padronizados) para um programa de desenvolvimento clínico de uma aprendizagem baseada em problemas. Evidências de instituições que utilizam essa metodologia será incluída na discussão com apreciação do âmbito e de sua aplicação prática. Descrição dos papéis de ambos (facilitador e aluno) no contexto de aprendizagem experiencial em pequenos grupos com pacientes padronizados serão fornecidas, bem como uma breve discussão sobre as técnicas de avaliação usando ambos feedback formativo e somativo. Este método utiliza cenários derivados de casos reais que são estruturados para proporcionar desafios comumente encontrados. Utiliza-se de pacientes padronizados treinados para retratar pacientes e dar imediato feedback aos estudantes. Aprendizado com simulação ao vivo dá aos participantes uma verdadeira oportunidade de aprendizagem experiencial na sala de aula, sem risco de prejudicar pacientes reais. Um cenário de prática realista permite que os aprendizes pratiquem e recebam um valioso feedback de outros alunos, professores e pacientes padronizados. Este artigo descreve uma aplicação deste método no ensino médico para ensinar aos alunos a comunicação centrada no paciente.

Descritores: Aprendizado ativo; Currículo baseado em problematização; Aprendizado experimental; Pacientes simulados; Educação de graduação em medicina. 


\section{Resumen}

La enseñanza en grupos pequeños se utiliza con frecuencia en la educación médica para dar la oportunidad de que el desempeño de la instrucción se base en la resolución de problemas, la comunicación y el trabajo en equipo. Los principios que ponen en práctica para ayudar a que los estudiantes de medicina aprendan a evaluar y controlar sus pacientes pueden ser integrados en grupos pequeños para la educación formativa. En este artículo se describe la aplicación de un modelo exitoso de interacción basado en la simulación humana (pacientes estandarizados) para el programa de desarrollo clínico en un ambiente de aprendizaje basado en problemas. La evidencia de instituciones que usan esta metodología será incluida en la discusión para evaluar el alcance y la aplicación práctica. La descripción tanto del docente facilitador como los roles del estudiante en ambientes de aprendizaje experimental de grupos pequeños con pacientes estandarizados será proporcionada, así como una breve exposición de las técnicas de evaluación que utilizan la retroalimentación formativa y sumativa. Este método usa escenarios derivados de ejemplos de casos reales que están estructurados para proporcionar retos comunes. Utiliza pacientes estandarizados entrenados para representar a pacientes y dar retroalimentación inmediata y en directo a los estudiantes. Las simulaciones a los estudiantes en directo ofrecen a los participantes una oportunidad de aprendizaje auténtica y empírica en una aula de clases, sin riesgo de dañar a pacientes reales. Un escenario práctico realista permite a los estudiantes practicar y recibir retroalimentación valiosa de otros estudiantes, docentes y pacientes estandarizados. Este artículo describirá una aplicación de este método en la educación médica para enseñar la comunicación centrada en el paciente a los estudiantes..

Palabras clave: Aprendizaje activo; plan de estudios, aprendizaje basado en problemas; Aprendizaje experimental; Simulación de paciente; Educación de pregrado en medicina.

\section{Introduction}

The use of standardized patients (SPs) in Medical Education is a methodology that since its inception in the late 1970's has changed the face of clinical education. ${ }^{1}$ Standardized patients are individuals trained to portray patients based on actual cases developed by clinical faculty. After training, a single case may be performed by multiple standardized patients over multiple iterations with accuracy, so that students will essentially see the "same patient." Another method of using standardized patients is to train single standardized patients on separate cases to be performed numerous times, as in a clinical skills examination (CSE). The CSE is sometimes referred to as an OSCE or objective structured clinical examination. This performance based method of standardize patients is used in clinical skills teaching in small groups as well as in one-to-one formative and summative assessments. In small group settings learners can observe and practice needed capabilities. In order to learn and retain communication skills, they need to be practiced with repetitions in a systematic way.

Practice can improve learning in several ways. Through systematic repetition students will permanently remember new information by transferring it into their knowledge base. Practice also improves the students' application of know- ledge automatically without reflection, allowing students' cognitive resources to handle more challenging tasks such as diagnosis development. ${ }^{2}$ SPs may often be seen as more credible than learners' classmates when providing feedback on interpersonal skills. Using the same SP for multiple interviews can demonstrate how different an interview can go based on the questions of the interviewer. Even though clinical skills may be best learned in a clinical setting, preparing the learner by challenging them with simulated clinical settings can allow practice for some of the more basic skills such as critical thinking, problem-solving, physical assessment, active listening, patient-centered communication and team building prior to needing to apply them in a clinical environment. $^{3}$

According to Palmer (2007) in The Courage to Teach, some problems associated with leading effective small groups include the teacher lecturing or generally talking too much, the hesitancy of students to participate in group discussion and students expecting to receive the solution rather than discussing and creating solutions independently of faculty providing the answer. ${ }^{4}$ The combined experience of utilizing faculty facilitation and standardized patients in a small group setting may be daunting to novice facilitators or to facilitators who have not used the SPin the small group. This article describes a process for 
facilitating a small group that has a standardized patient presented to it as a medical case. The use of SPs can help bring problem-based learning to a realistic application and help facilitate the learning of interpersonal skills through practice and feedback.

\section{Development}

The goal for any encounter using a standardized patient (SP) is to improve or test communication skills of an individual or a team through performance and feedback. It is suggested that when developing protocols for use of SPs in a small group, several considerations be made. First, the size of the small group should be limited to a number which can allow each student to be an interviewer over the course of several simulations. Group size of 6-8 students is manageable and allows room for all students to participate either in a single setting or over time. For example, if two students are allowed to interview for each individual case and the small group is limited to six students; three standardized patient cases would be used during the course to give each student an opportunity to interview the patient. Group size is an institutional decision and has a great deal to do with class size and number of faculty.

To begin, it is important to find a common vocabulary for this type of simulation. According to the Association of Standardized Patient Educators, the international association for trainers, a standardized patient is "an individual hired and trained to portray the actual patient, presenting a faculty defined clinical scenario with patient history and physical symptoms for teaching and assessment purposes." 5

Kenyon (2002) adds further definitions to human simulation scenarios. Student interviewers are those students in a class who are directly working with the SP. There may be multiple student interviewers during a small group session as will be explained later. Student observers are the members of the group who observe and take notes during the clinical encounter. Student observers provide feedback and offer suggestions to the student interviewers at the appropriate time. Facilitators are usually the instructors for the class, or, in a Problem Based Learning group, it may be a group member who is managing the clinical encounter. Facilitators provide guidance and feedback before and after the encounter but should avoid interjecting during the interview and small group process.

\section{Case development}

Clinical scenarios are best developed using an actual patient case. Using real cases provides the most realistic and therefore most effective cases. There are many resources for finding cases written for standardized patients. The Association of Standardized Patient Educators publishes several cases on their website for members of the association. ${ }^{6}$ Other examples of places to find cases include medical schools with a standardized patient program that may have case banks in-house and MedEdportal. A simple web search of "standardized patient cases" can locate numerous resources. However, if the course objectives require a specific scenario the following suggestions may help in the development of those cases. Each scenario consists of four basic parts: character protocols, presenting situation, an initial information page, and a checklist for providing feedback. The case scenario contains detailed information from the patient's perspective such as who they are, including personal family history, appearance, affect, and internal thoughts or feelings. Case development should include the nature of their presenting condition and how it is affecting them, and what have they done (if anything) to address the condition prior to coming in to the clinic. It is important to include the standardized patient's emotional state prior to the encounter and any emotional changes throughout the encounter if appropriate. For example, a patient may be quite anxious at the outset of the encounter, but relax and be more forthcoming with an empathetic interviewer. The case materials for the standardized patient would not include any information that a patient would not know themselves. Any clinical information or facilitator guidelines would be in another section of the training materials.

\section{Learning goals and objectives}

Before selecting a scenario, learning objectives for the class should be determined. With a standardized patient involved, the learning goal might be "To improve investigative interviewing 
skills" or "To practice interviewing a difficult patient." ${ }^{5}$ The learning objectives for the class may accompany the goals. For example, if the learning goal is to improve investigative interviewing skills, then the learning objectives might be: 1)to give students the opportunity to practice using age appropriate language, 2) to introduce issues of cultural diversity and cultural competency, 3) to provide practice applying clinical interviewing steps.

\section{The learning event}

Preparation for the learning event includes determining the group size, student level of ability and time allowed for the event. Smaller groups provide more opportunities for students to practice their skills and receive pertinent and specific feedback. Orientation to the learning event would include a description of the purpose of the event, expectations, and procedures.

Allowing students to understand these concepts can assuage their fears. Students often feel anxious in front of their peers and their faculty. A safe learning environment that allows and acknowledges the benefits of making mistakes and of positive feedback will reduce some of these tensions. Observers who will be providing feedback need to be in close enough proximity to the simulation to hear normal conversational tones of the interview, but not so close as to interfere in the simulation.

\section{Format for the small group learning event}

There are three basic formats for a small group session involving standardized patients in simulated interviews. Of course there may be variations on these themes.

Format 1:One learner interviews at a time and each subsequent interviewer begins the interview where the preceding interviewer stopped. This format provides flow and gathering of a great deal of information.

Format 2: One learner begins the interview from the beginning and subsequent interviewers begin again at the beginning. This format provides students an opportunity to learn from the previous interviewers' errors and can improve the overall flow of the interview. Less information will be gathered in format 2 than in format 1; thus, format 2 is generally reserved for assessment purposes.

Format 3: One learner completes the entire interview with the standardized patient(s) from beginning to end. Other students observe, discuss, and give feedback. This format provides a more realistic flow to the interview, but limits the engagement of the other students in practicing the interview.

\section{Facilitating the simulation}

The facilitator has an active role during the simulation. Facilitators are aware of the dynamics between the interviewer and the SP in order to mediate feedback between observers and interviewers. They will identify and utilize teaching opportunities without disrupting the interview, addressing issues at the appropriate time. In scenarios where feedback is desired from the SPs, the facilitator will mediate this activity. Most importantly, the facilitator will provide a safe or non-threatening environment for all students in which it is possible to make errors without fear of ridicule or grading. For SPs it is critical that corrective feedback be given by the facilitator to the trainer after the encounter in order for continuous quality improvement be made. Using Time Out: When using standardized patients in a small group setting, it is common for a time out format to be utilized. The time out is taken by the interviewer at a moment when they find themselves out of further questions or directions that the interview might take. It is important that the student interviewer be the only one to interrupt the interview with a time out in order to allow them to be thoughtful and take pauses as necessary, with the opportunity to seek help from their classmates as needed. The class should not call a time, nor the facilitator, unless there is an obvious need for the interviewer to be interrupted. Facilitators should remember that, in the safe environment of the simulation, it is not only expected, but also educational for the student interviewer to make errors.

Time out periods allow learners to analyze, reflect, and problem-solve. Feedback from the class may be provided to the interviewer regarding direction of subsequent questioning and clarifying questions that the interviewer may 
ask. The timeout provides an opportunity for hypothesis development, sharing observations and developing alternative strategies. The student interviewer may call for a time in at any moment and continue the interview. During a time out period, SPs should not engage with the interviewer or the class. This is a time for the SP to go in to repose and reflect on their portrayal and consider answers to questions that the learner may soon ask.

If formats 1 or 2 are used in the clinical simulation, student interviewers may switch during the time out. The facilitator may use the time out as an opportunity to probe the class for their thoughts on the clinical case at this point.

\section{Feedback}

SPs will not provide feedback to the student interviewer(s) until the conclusion of the simulation. The focus of the feedback may be mediated by the facilitator. SPscan give feedback on interpersonal and communication skills including the opening, questioning skills, active listening, body language, perceived bias, summarizing, facilitation of the interview by the student interviewer, client perspectives, pacing of the interview and closure. The SP should refrain from providing any feedba$\mathrm{ck}$ regarding the clinical nature of the presenting condition, or any information left out of the interview. This is best left to the facilitator after the feedback session is complete. Once the SP is finished with feedback, the facilitator may thank them and allow them to leave the small group.

\section{Debriefing the simulation}

Once the SP has left the room, the facilitator may want to debrief the simulation with the small group. Especially in emotionally charged scenarios, the class may need to decompress and analyze their feelings after the encounter. An opportunity for reflection often will allow participants to gain insight into their own biases, concerns, and future goals. For those learners it may be beneficial to re-visit the simulation at a subsequent class for a brief reflection. Facilitators may also want to provide feedback to the faculty on the ability of the scenario to fulfill the course objectives. 7

In conclusion we presented an interactive activity that allows students to practice clinical interviewing skills in a safe environment, with the opportunity to receive both positive and constructive feedback from fellow classmates, faculty and standardized patients. The small group setting using standardized patients is efficient and feasible as essentially each small group sees the same "patient" in a controlled environment. Students may be provided clinical cases that may be of an emotionally charged nature, or a case that is non-existing in the clinical setting at the given moment. The opportunity for "Time Out" allows the learner to question classmates provoking critical thinking within the class and problemsolving as a group.

\section{References}

1. Barrows H. Simulated (Standardized) Patients and Other Human Simulations. Chapel Hill: Health Sciences Consortium; 1987.

2. Lane C, Rollnick S. The use of standardized patients and role-play in communication skills training: a review of the literature to August 2005. Patient Education Counseling 2007; 67 (1-2): 13=20.

3. Brabeck M, Jeffrey J. Practice for knowledge acquisition (not drill and kill): Designing activities with the goal of transferring knowledge. American Psychological Association. Available from: http://www.apa.org/ education/k12/practice-acquisition.aspx.

4. Jaques D.ABC of learning and teaching in medicine: teaching small groups. BMJ. 2003;326:492.1.http:// dx.doi.org/10.1136/bmj.326.7387.492

5. Palmer P. The courage to teach: exploring the inner landscape of a teacher's life. 10th anniversary ed. San Francisco: Jossey-Bass.2007.

6. Kenyon G, Developing a live simulation program for social work education in child welfare. North Carolina Child Welfare Education Collaborative; 2002.

7. Association of Standardized Patient Educators. (Internet): Standardized Patient and Simulation Terminology Standards of Practice;2014. Available from: http://www.aspeducators.org/node/102. Access on: May 27, 2014.

\section{Heidi A. Lane}

Clinical Skills Assessment \& Education. Department of Medical Education. Virginia Tech Carilion School of Medicine. Roanoke, VA, United States.

\section{Beth H. Ipock}

Standardized Patient Program. Department of Medical Education. Virginia Tech Carilion School of Medicine. Roanoke, VA, United States. 